\title{
Tracheal intubation in morbidly obese: A comparison of Airtraq and
}

\section{intubating laryngeal mask airway}

\section{Canan Turna, Zehra Ipek Arslan, K Okyay, Volkan Alparslan, Mine Solak}

Aim: In morbid obesity, various difficulties in intubation and ventilation are confronted due to increased fat tissue in the upper airway and diminished compliance in the chest wall. Airtraq, a disposable video laryngoscope, is used for both normal and difficult intubations without the need for the same level of oral, pharyngeal, and laryngeal axis ${ }^{1}$. ILMA is a preferred blind airway device in difficult airway and ventilation, used for ventilation during intubation. ${ }^{2}$ We aimed to compare ILMA and Airtraq in terms of placement and intubation times, trial counts, intubation success rates, maneuvering requirements, haemodynamic parameters and complications in morbidly obese patients with a $\mathrm{BMl}>35$.

Material and method: After receiving ethics committee approval and informed consent, 80 patients were included in the study, between ASA 1-3 and 18-60 years of age, who required intubation to undergo elective surgery. The patient was premedicated with intravenous midazolam at a dose of $0.03 \mathrm{mg} / \mathrm{kg}$. Demographic data of the patients were recorded. Anesthesia was induced with propofol and fentanyl following standard anesthesia monitoring. Rocuronium was used as muscle relaxant. Anesthesia was continued with $2 \%$ sevoflurane in a mixture of $60 \% \mathrm{~N}_{2} \mathrm{O}+\mathrm{O}_{2}$. The patients were randomly divided into two groups, Airtraq and ILMA.
Results: The demographic data and airway characteristics of the patients were similar.

Table 1. Airway management variables of patients

\begin{tabular}{|c|c|c|c|c|}
\hline & $\begin{array}{c}\text { Airtraq } \\
\mathrm{n}: 40\end{array}$ & $\begin{array}{c}\text { ILMA } \\
\text { n:39 }\end{array}$ & $\mathrm{p}$ & \\
\hline $\begin{array}{c}\text { Number of } \\
\text { attempts } \\
\text { I/II/III }\end{array}$ & $34 / 6 / 0$ & $31 / 7 / 1$ & & 0,6 \\
\hline Insertion time (s) & $\begin{array}{c}14,6 \pm 1 \\
1,3\end{array}$ & $\begin{array}{c}15,7 \pm \\
6,4\end{array}$ & & 0,06 \\
\hline Intubation time (s) & $\begin{array}{c}29,9 \pm 2 \\
2,1\end{array}$ & $\begin{array}{c}50,7 \pm 2 \\
1,2\end{array}$ & $\begin{array}{l}<0, \mathrm{C} \\
01 \dagger\end{array}$ & \\
\hline Total intubation time (s) & $\begin{array}{c}29,9 \pm 2 \\
2,1\end{array}$ & $\begin{array}{c}97,4 \pm 4 \\
2,7\end{array}$ & $\begin{array}{l}<0, \mathrm{C} \\
01 \dagger\end{array}$ & \\
\hline $\begin{array}{c}\text { Maneuver } \\
\text { Present/Abscent }\end{array}$ & $22 / 18$ & $16 / 23$ & & 0,3 \\
\hline $\mathrm{SPO}_{2}$ & $\begin{array}{l}98,9 \pm 1 \\
, 2\end{array}$ & $\begin{array}{c}98,7 \pm \\
2,1\end{array}$ & & 0,7 \\
\hline
\end{tabular}

There was no statistically significant increase in mean arterial pressure when the heart rate increased in the Airtraq group after placement. In the ILMA group, mean arterial pressure increased while heart rate did not increase. Airtraq and ILMA were similar in terms of postoperative complications.

Conclusion: Airtraq seems superior to ILMA in morbidly obese patients with low oxygen reserve and rapid desaturation, with a total intubation time of less than 60 seconds compared to ILMA. 